Vol 10, Issue 12, 2017

\title{
STUDY ON APHRODISIAC ACTIVITY OF OLEA DIOICA ROXB. BARK, LEAF EXTRACTS, AND ITS PURE COMPOUND USING WISTAR ALBINO RATS
}

\author{
ASHWATHANARAYANA R*, RAJA NAIKA \\ Department of PG Studies and Research in Applied Botany, Kuvempu University, Jnanasahyadri, Shankaraghatta, Shimoga - 577 451, \\ Karnataka, India. Email: ashwinjamadagni497@gmail.com
}

Received: 11 July 2017, Revised and Accepted: 16 August 2017

\section{ABSTRACT}

Objectives: We aimed to assess the effects of 0 . dioica Roxb. leaf and bark extract and its isolated constituent benzeneethanol, 4-hydroxy- on aphrodisiac activity in rats using different standard aphrodisiac parameters.

Methods: To determine the aphrodisiac activity several parameters were observed. These include measuring and observing the mount frequency (MF), mount latency (ML), intromission frequency (IF), intromission latency (IL), anogenital sniffing (AS), and genital grooming (GG).

Results: The aphrodisiac activity of 0 . dioica Roxb. leaf and bark extracts and its pure compound were studied on Wistar albino rats at different dosages. The parameters observed during the study were MF, ML, IF, IL, AS, and GG. The results revealed that the crude extracts showed dosedependent activity in all the concentration, in that, ethanolic leaf extract showed excellent activity compared to ethanolic bark extract and pure compound benzene ethanol 4-hydroxy.

Conclusion: Results showed the excellent aphrodisiac activity of $O$. dioica Roxb. leaf and bark ethanolic extracts. However, the major compound benzeneethanol, 4-hydroxy- was not responsible for the aphrodisiac activity, may be the minor compounds even though in minor concentration in the extract influence the sexual activity in tested animals.

Keywords: Olea dioica Roxb, Benzene-ethanol, 4-hydroxy-, Aphrodisiac activity, Mount frequency, Mount latency, Intromission frequency, Intromission latency, Anogenital sniffing, Genital grooming.

(C) 2017 The Authors. Published by Innovare Academic Sciences Pvt Ltd. This is an open access article under the CC BY license (http://creativecommons. org/licenses/by/4. 0/) DOI: http://dx.doi.org/10.22159/ajpcr.2017.v10i11.21197.

\section{INTRODUCTION}

In all the historic literature of Indian, Chinese, Egyptian, Roman, and Greek cultures, there was a mention of many plant-based substances for the purpose of improving the sexual capability [1], the word aphrodisiac came from the Greek God Aphrodite, goddess of love and beauty [2].

The sexual function involves central and peripheral neuronal activity, hormonal activity, and peripheral cellular activity. Compared to other tricyclic antidepressants, it has a greater effect on dopamine blockade and serotonin reuptake inhibition $[3,4]$.

From manyplants, numerous number of compounds scientifically proved for its Aphrodisiac activity, such as Yohimbine hydrochloride from the Yohimbe (Pausinystalia johimbe) trees of West Africa, protodioscin from Tribulus terrestris, Icariin from Horny goat weed (Epimedii herba) from China, HV430 from Muira Puama (Ptychopetalum olacoides) a Brazilian plant, MACA ethanolic extract of MACA (Lepidium meyenii) from Andes, extracts of Ginseng (Panax ginseng) a plant from Korea, ethanolic extract of Nutmeg (Myristica fragrans) native to India, Indonesia, and Sri Lanka, crocin and safranal from Saffron (Crocus sativus) native to the Middle East, phenylethylamine and $\mathrm{N}$-acylethanolamine from cocoa Theobroma cacao native to tropical regions in South America and Africa and many animal origin compounds such as the triterpene alcohol ambrein form whale (Physeter catodon), cantharidin from Spanish fly (Lytta vesicatoria), bufotenine and its 0-methylated derivative 5 methoxy-M,N-dimethyltryptamine from Bufo Toad (Bufo alvarius) [2] Yohimbine is an indole alkaloid derived from the bark of the $P$. johimbe [5] tree in Central Africa were also confirmed for their aphrodisiac activity.
The Western Ghats comprises of a hill range running about $1500 \mathrm{~km}$ along the Western edge of Indian subcontinent. Although it covers a mere $5.00 \%$ of the country's total land area in the country, it is believed to be more than $27.00 \%$ of country's plant species remarkably high level of endemism ranging from $25.00 \%$ to $60.00 \%$ of recorded species in various taxa $63 \%$ of Indian evergreen tree species are believed to be endemic to that area [6].

From a survey conducted by the Indian Council of Medical Research on Ethnomedicinal Plants of Western Ghats, India, reported more than 500 medicinal plants throughout the Western Ghats, used by the traditional medicinal practitioner for different diseases [7].

Olea dioica Roxb. taxonomical hierarchy.

\begin{tabular}{ll}
\hline Kingdom & Plantae \\
\hline Phylum & Tracheophyta \\
Class & Magnoliopsida \\
Order & Lamiales \\
Family & Oleaceae \\
Genus & Olea \\
Species & O. dioica Roxb. \\
\hline
\end{tabular}

O. dioica: Olea dioica

O. dioica Roxb. is an important ethnomedicinal tree belonging to the family of Oleaceae. The tree grows up to $15 \mathrm{~m}$ tall. The bark of the tree is brownish, rough, blaze pale brown. Young branchlets are subquadrangular, lenticellate, and glabrous. Leaves are simple, opposite, decussate; petiole 0.6-1.3 cm long, canaliculate; lamina $7.5-17.5 \mathrm{~cm} \times 2.3-7.5 \mathrm{~cm}$, elliptic to elliptic-oblong, apex gradually 
acuminate to subacute, base acute or attenuate, margin distantly serrate (with strong teeth) or entire, coriaceous to subcoriaceous, glabrous; midrib flat above, usually reddish when dry; secondary nerves 8-12 pairs; tertiary and higher order nerves obscure or slightly impressed. Inflorescence axillary divaricate panicles; flowers polygamodioecious, cream-white; pedicel $0.4 \mathrm{~cm}$ long. Fruit is drupe, ellipsoid, blue when ripe; one-seeded. Roots of the plant have medicinal properties and are used for the treatment of cancer and snake bite in Siddha medicine. In Maharashtra, the tribes use 0 . dioica Roxb. fruits for the treatment of skin disease. Bark and fruit paste are used in rheumatism; decoction of the bark is used to wash old wounds and given to counter fever [8]. Ripe fruits are traditionally used by the tribes in Kerala forest [9]. O. dioica leaf ethanolic extract showed appreciable antibacterial, antifungal activity, antioxidant, and cytotoxic properties [10-12].

The study was conducted in Sharavathi Wildlife Sanctuary, Shivamogga, Karnataka, to document the Tree diversity revealed that 0 . dioica is the most frequently distributed and species with density, basal area and was emerged as most important tree species found in evergreen, semievergreen, and moist deciduous forest of the area [13].

Despite meager work on this plant 0 . dioica, a very important medicinal plant was not explored for many pharmacological activities. Therefore, the aim of the study was to prove the aphrodisiac potential of $O$. dioica Roxb. leaf and stem extract collected from the forest of Central Western Ghats, Karnataka.

\section{METHODS}

\section{Study area}

The study area was Sagara - moist deciduous forest types of Western Ghats, within Karnataka state, India, with altitude range 630-840 m. The study area is situated in Shimoga (140 $08^{\prime} 48^{\prime \prime}$ N $74^{\circ} 57^{\prime} 25^{\prime \prime}$ E) (Fig. 1).

\section{Identification}

The botanical identification of the plant was done using Flora of Madras - Gambler and it was confirmed by Prof. K G Bhat, Udupi, and the voucher specimen was conserved under the reference number $\mathrm{KU} / \mathrm{AB} /$ RN/AS/001.

\section{Preparation of the extract}

The plant samples were shade dried for about 30-45 days and mechanically powdered. Powdered material was subjected to Soxhlet extraction [14] successively with petroleum ether, chloroform, and ethanol. Samples were air-dried and kept in an air tight bottles.

\section{The qualitative preliminary phytochemical analysis}

Extracted plant samples were screened for the presence of tannins, alkaloids, saponin, glycosides, flavonoids, steroids/sterols, and phenols using the standard $[15,16]$.

\section{Gas chromatography and mass spectroscopy (GC-MS) analysis} GC-MS of plant extract was done in Vittal Mallya Scientific Research Foundation, Bengaluru. Plant extracts were subjected to GC-MS analysis and obtained spectra were analysed. GC model: Thermo trace GC Ultra, MS model: Thermo DSQ II, ionization: Electron impact ionization (EI), chemical ionization, mass range: $1-1074 \mathrm{~m} / \mathrm{z}$.

\section{Animals}

Wistar albino rats of both sex weighing between 180 and 200 g were obtained and kept in the laboratory. The animals were maintained under standard environmental conditions and had free access to standard diet and water. Plant extracts were administered orally by gavage in distilled water at different dose levels. The study was permitted by the Institutional Animal Ethical Committee (Reg. No. SCSCP/IAEC/11/12/2016-17), India.

\section{Preparation of male rats}

The male rats were prepared for sexual activity, two times a day for a period of a minimum of 10 days. The one which did not show any sexual interest during the 10 days of the period was considered as an inactive male.

\section{Preparation of female rats}

Female rats were kept in separate cages providing with food and water. The female rats were brought in estrous phase by treating them with estradiol valerate (10-50 $\mu \mathrm{g}$ ) for adult rats depends on the body weight).

\section{Experimental details}

The sexually active male rats were selected and divided into seven groups; each group consisting of six animals. The groups were designed as follows, control (normal saline) $2 \mathrm{ml} / \mathrm{kg}$ body weight, positive control (sildenafil citrate) $4.5 \mathrm{mg} / \mathrm{kg}$ body weight, ethanolic leaf extracts in 200 and $400 \mathrm{mg} / \mathrm{kg}$ body weight, ethanolic bark extract in 200 and $400 \mathrm{mg} / \mathrm{kg}$ body weight, pure compound benzene-ethanol, 4-hydroxy- in $4.5 \mathrm{mg} / \mathrm{kg}$ body weight. The sexual behavior of the experimental rats was observed in a dim light in specially designed cages that have glasses on all the sides and measuring $50 \mathrm{~cm} \times 30 \mathrm{~cm} \times$ $30 \mathrm{~cm}$. The male rat was first placed in the cage, and then two female rats in estrous phase were introduced. An initial period of 15 minutes was considered as acclimatization period. The experimental extract and the pure compound were introduced 15 minutes after acclimatization period. The activity of male rat in each group was recorded individually for 60 minutes, after 30 minutes of drug administration [17-20]. To determine the aphrodisiac activity of the extracts, several parameters were observed. These include measuring and observing the mount frequency (MF), mount latency (ML), intromission frequency (IF), intromission latency (IL), anogenital sniffing (AS), and genital grooming (GG) [21].

\section{$M F$}

Mounting is defined as the climbing of one animal by another usually from the posterior end with the intention of introducing one organ into another. Mount may also be operationally defined as the male assuming the copulatory position but failing to achieve intromission. MF is therefore defined as the number of mounts without intromission from the time of introduction of the female until ejaculation.

\section{IF}

Intromission is the introduction of one organ or parts into another. For example, the penis into the vagina. IF is therefore defined as the intromissions from the time of introduction of the female until ejaculation.

$M L$

ML is defined as the time interval between the introduction of the female and the first mount by the male.

$I L$

IL is the time interval from the time of introduction of the female to the first intromission by the male. This is usually characterized by pelvic thrusting and springing dismounts.

AS

AS is defined as sniffing of the genital part by the experimental male rat after the introducing the test drug. AS count is the number of sniffing of genitals in a given interval of time was recorded.

GG

GG is defined as licking of the genital part by the active male with its tongue after test drug administration. Hence, GG count is the number of grooming of genital in a given interval of time was recorded.

\section{Acute toxicity studies}

Rats of both sexes (three females and three males, weight: 25-35 g, age: 6-8 weeks) received an ethanolic extract of 0 . dioica leaf and bark starting at $2 \mathrm{~g} / \mathrm{kg}$ orally by gavage. The animals were observed for 


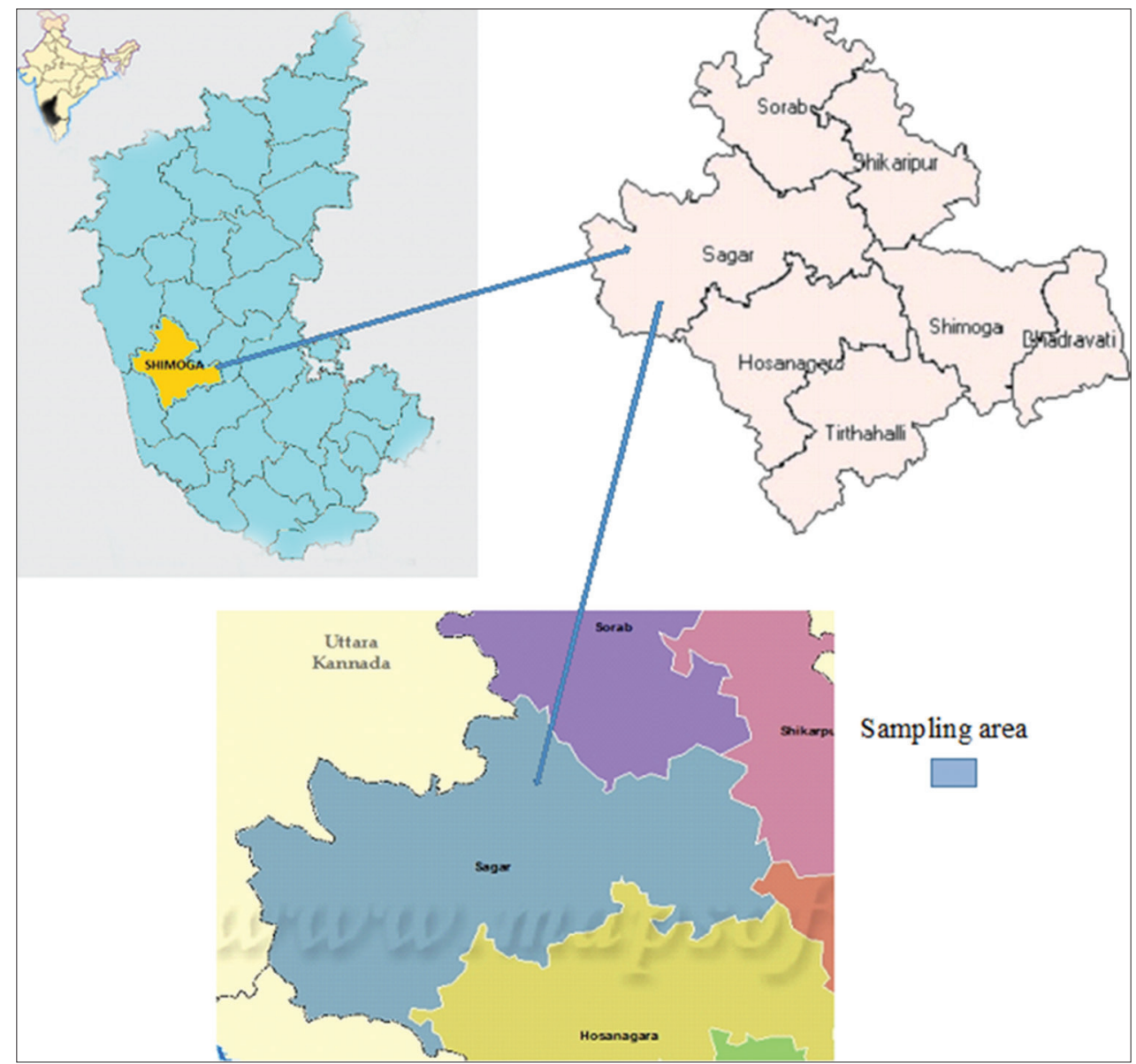

Fig. 1: Sampling site details and location

toxic symptoms continuously for the first 4 hrs after dosing. Finally, the number of survivors was noted after $24 \mathrm{hrs}$ and these animals were then maintained for further 13 days with observations made daily [22]. The acute toxicity studies were carried out according to OECD guidelines -425 .

\section{Statistical analysis}

The mean value \pm standard error of mean was calculated for each parameter. Results were statistically analyzed by one-way analysis of variance (ANOVA) followed by Dunnet's t-test. Symbols represent statistical significance. ${ }^{*} \mathrm{p}<0.05,{ }^{* *} \mathrm{p}<0.01,{ }^{* * *}<0.0001$, ns - not significant, as compared to control group.

\section{RESULTS}

\section{Extract yield and preliminary phytochemical analysis}

The soxhlet extraction of $O$. dioica leaf $(750 \mathrm{~g})$ with petroleum ether gives $8.14 \mathrm{~g}$, with chloroform gives $13.32 \mathrm{~g}$ and with ethanol gives $65.32 \mathrm{~g}$ yield. The soxhlet extraction of 0 . dioica bark $(750 \mathrm{~g})$ with petroleum ether gives $8.14 \mathrm{~g}$, with chloroform gives $13.32 \mathrm{~g}$ and with ethanol gives $65.32 \mathrm{~g}$ yield. The results of preliminary qualitative phytochemical screening of different extracts of 0 . dioica leaf indicate the presence of saponins, flavonoids, steroids/sterols, glycosides and phenols in the ethanolic crude extract, the chloroform and petroleum ether crude extract gave negative results for all these compounds.

In $O$. dioica bark ethanolic extracts indicate the presence of saponins, flavonoids, steroids/sterols, glycosides and phenols, and the chloroform crude extracts shows positive results for tannins and flavonoids, but the petroleum ether crude extract gave negative results for all these compounds. Hence, the experiments we took only ethanolic leaf and bark extracts (Table 1).

\section{GC-MS analysis of ethanolic crude extract Leaf ethanolic extract}

In GC-MS analysis of medicinal 0 . dioica, ethanolic leaf extract revealed the presence of 38 compounds, in that major percentage of compounds present, was benzene-ethanol, 4-hydroxy- (37.44), 2-amino-3-(3,4dihydroxy-phenyl)-propionic acid (L-Dopa) -(16.47), 1,3-benzenediol, 4-propyl- (6.46), 2,4-dimethoxytoluene - (5.01), benzaldehyde, 2,3-dimethoxy - (4.63). The compounds such as benzene-ethanol, 4-hydroxy- $(37.44 \%)$ has antioxidant and cytotoxic properties. 2-amino-3-(3,4-dihydroxy-phenyl)-propionic acid (16.47\%) has similar structure 99 percent similar to L-Dopa a psychoactive drug and also cytotoxic properties (Table 2 and Figs. 2-5).

\section{Bark ethanolic extract}

In GC-MS analysis of bark $O$. dioica ethanolic extract revealed the presence 37 compounds, in that benzene-ethanol, 4-hydroxy- (24.51), ethanone, $\quad 1$-[5-[(5-methyl-2-furanyl)methyl]-2-furanyl]- (18.05), ethanol, 2,2'-oxybis- (8.03), acetic acid, 5,7,8-trimethyl-6-coumarinyl ester (7.34), 2-furancarboxaldehyde, 5-(hydroxymethyl)- (6.82) in major percentage (Table 3 and Figs. 6-9).

\section{Acute toxicity studies}

The ethanolic extract of leaf and bark of plant $O$. dioica was found to be safe up to $2000 \mathrm{mg} / \mathrm{kg}$ body weight by the oral route. After $24 \mathrm{hrs}$, animals were found well tolerated. There was no mortality and no signs of toxicity and extract were found to be safe.

\section{Aphrodisiac activity}

The aphrodisiac activity of ethanolic leaf and bark extracts of $O$. dioica were studied on male Wistar albino rats at various dosages. The 
Table 1: Preliminary phytochemical analysis of different leaf and bark extract of 0 . dioica Roxb

\begin{tabular}{|c|c|c|c|c|c|c|c|}
\hline \multirow[t]{2}{*}{ Secondary metabolites } & \multirow[t]{2}{*}{ Type of tests } & \multicolumn{2}{|c|}{$\begin{array}{l}\text { Petroleum ether } \\
\text { crude extract }\end{array}$} & \multicolumn{2}{|c|}{$\begin{array}{l}\text { Chloroform crude } \\
\text { extract }\end{array}$} & \multicolumn{2}{|c|}{$\begin{array}{l}\text { Ethanol crude } \\
\text { extract }\end{array}$} \\
\hline & & Leaf & Bark & Leaf & Bark & Leaf & Bark \\
\hline \multirow[t]{2}{*}{ Alkaloids } & Mayer's test & - & - & - & - & - & - \\
\hline & Wagner's test & - & - & - & - & - & - \\
\hline Saponins & Foam test & - & - & - & - & + & + \\
\hline Tannins & Ferric chloride test & - & - & - & + & + & + \\
\hline \multirow[t]{4}{*}{ Flavonoids } & Shinda test & - & - & - & - & + & + \\
\hline & Zinc- $\mathrm{HCl}$ reduction test & - & - & - & - & + & + \\
\hline & Alkaline reagent test & - & - & - & - & + & + \\
\hline & Lead acetate test & - & - & - & + & + & + \\
\hline Steroids & Salkowaski test & - & - & - & - & + & + \\
\hline \multirow[t]{3}{*}{ Glycosides } & Keller-Killiani's test & - & - & - & - & + & + \\
\hline & Brown water test & - & - & - & - & + & + \\
\hline & Legal test & - & - & - & - & + & + \\
\hline \multirow[t]{2}{*}{ Phenols } & Ferric chloride test & - & - & + & - & + & + \\
\hline & Acetic acid test & - & - & + & - & + & + \\
\hline
\end{tabular}

-: Negative result, +: Positive result, O. dioica: Olea dioica

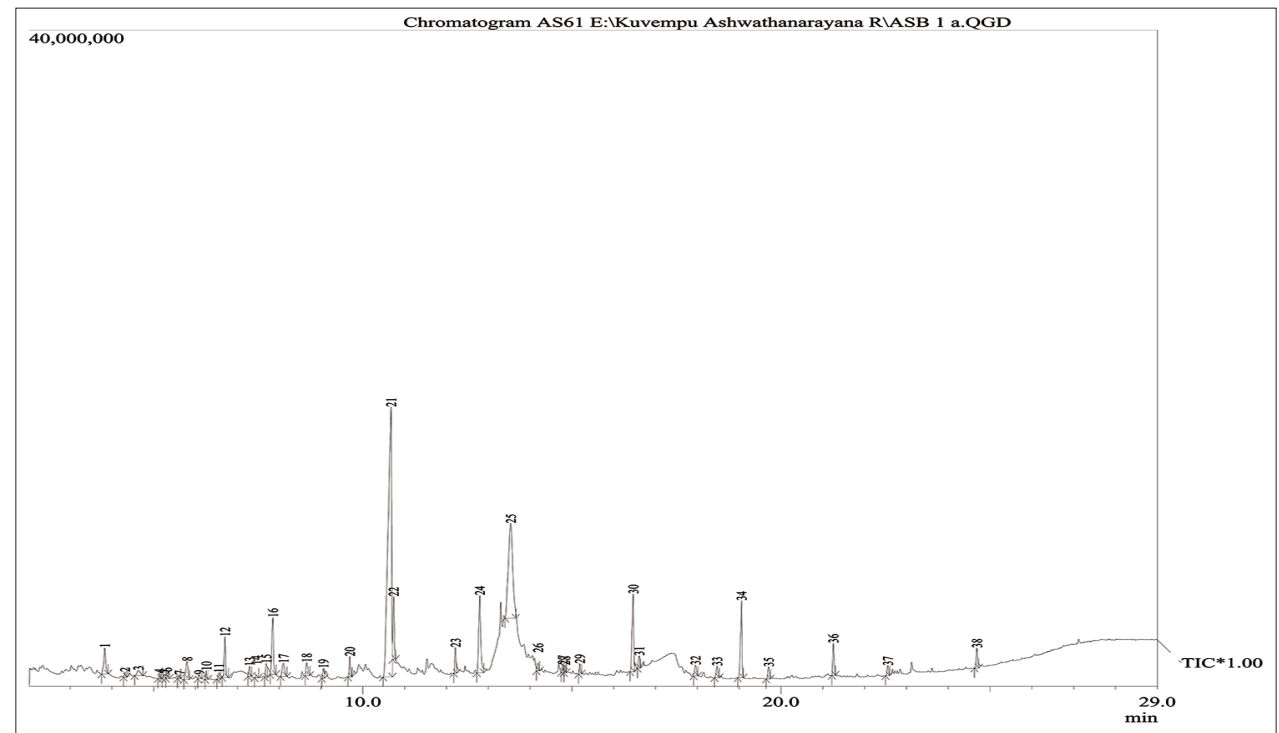

Fig. 2: Gas chromatography and mass spectroscopy chromatogram of Olea dioica leaf ethanolic extract

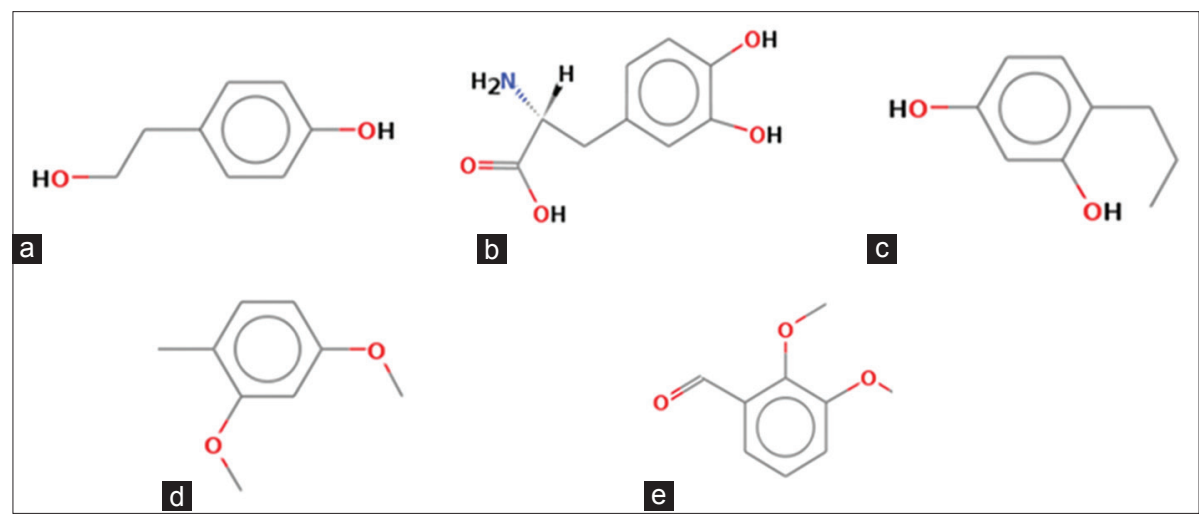

Fig. 3: Major percentage of constituent present in the gas chromatography and mass spectroscopy analysis of crude leaf ethanolic extract of Olea dioica Roxb. (a) Benzenethanol, 4-hydroxy-, (b) 2-amino-3-(3,4-dihydroxy-phenyl)-propionic acid, (c) 1,3-benzenediol, 4-propyl-,

(d) 2,4-dimethoxytoluene, (e) benzaldehyde, 2,3-dimethoxy- 
Table 2: List of identified of phytocompounds in crude leaf ethanolic extract of $O$. dioica Roxb. by GC-MS analysis

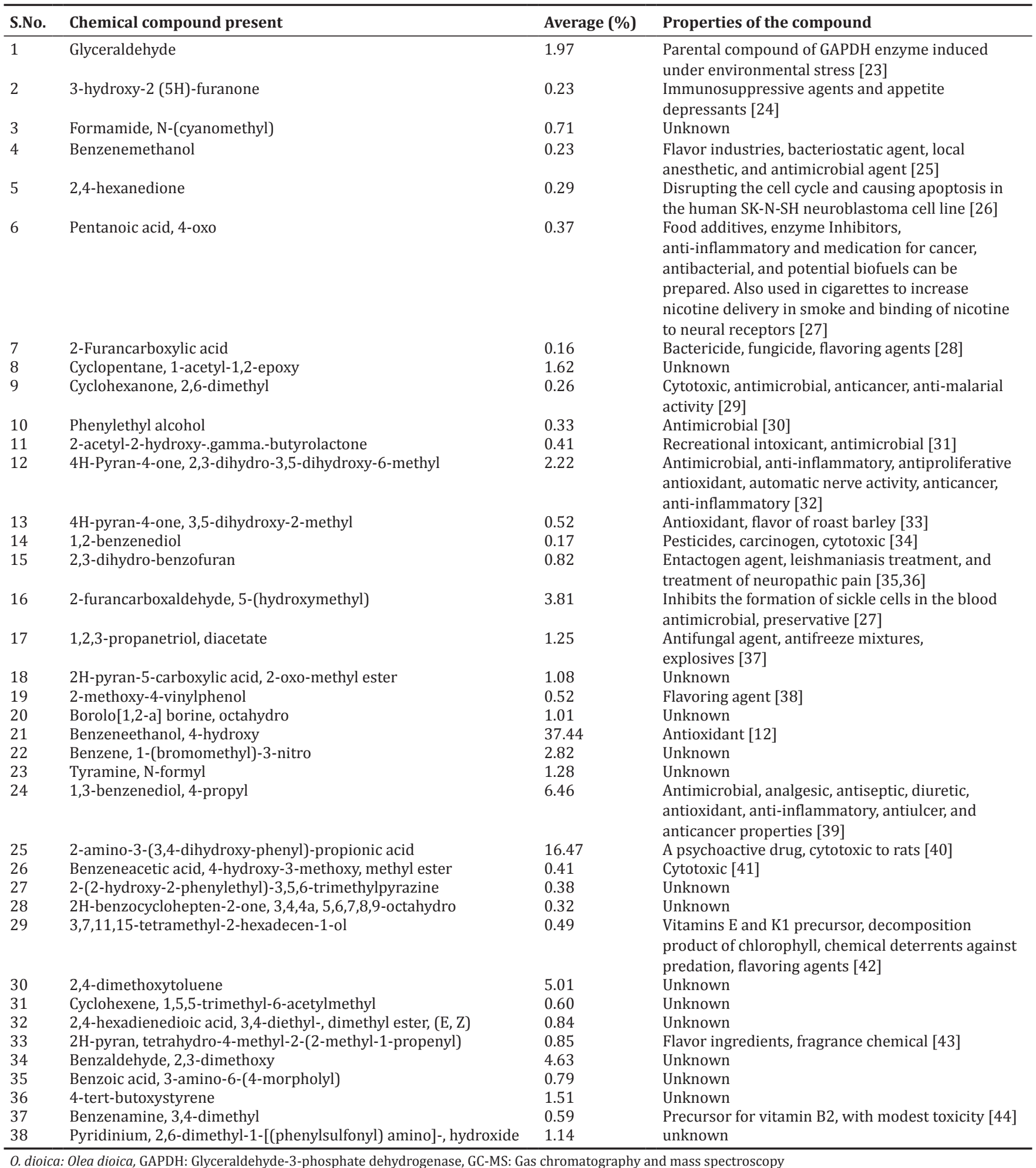

O. dioica: Olea dioica, GAPDH: Glyceraldehyde-3-phosphate dehydrogenase, GC-MS: Gas chromatography and mass spectroscopy

parameters observed during the study were MF, ML, IF, IL, AS, and GG (Table 4 and Fig. 10).

$M F$

By observing the results, it is revealed that all the crude extracts showed dose-dependent activity in all the concentration, in that ethanolic leaf extract $(9.66 \pm 0.32)$ and ethanolic bark extract $(7.33 \pm 0.32)$ showed highest MF at $400 \mathrm{mg} / \mathrm{kg}$ body weight. Whereas, ethanolic extracts at $200 \mathrm{mg} / \mathrm{kg}$ body weight also showed appreciable activity (leaf: $5 \pm 0$; bark: $4.66 \pm 0.32$ ) activity. On the other hand, the pure compound benzene ethanol 4 hydroxy- $(4 \pm 0) 4.5 \mathrm{mg} / \mathrm{kg}$ body weight showed negligible MF compared to all the extract used. Therefore, the above 
Table 3: List of identified of phytocompounds in crude bark ethanolic extract of $O$. dioica Roxb. by GC-MS analysis

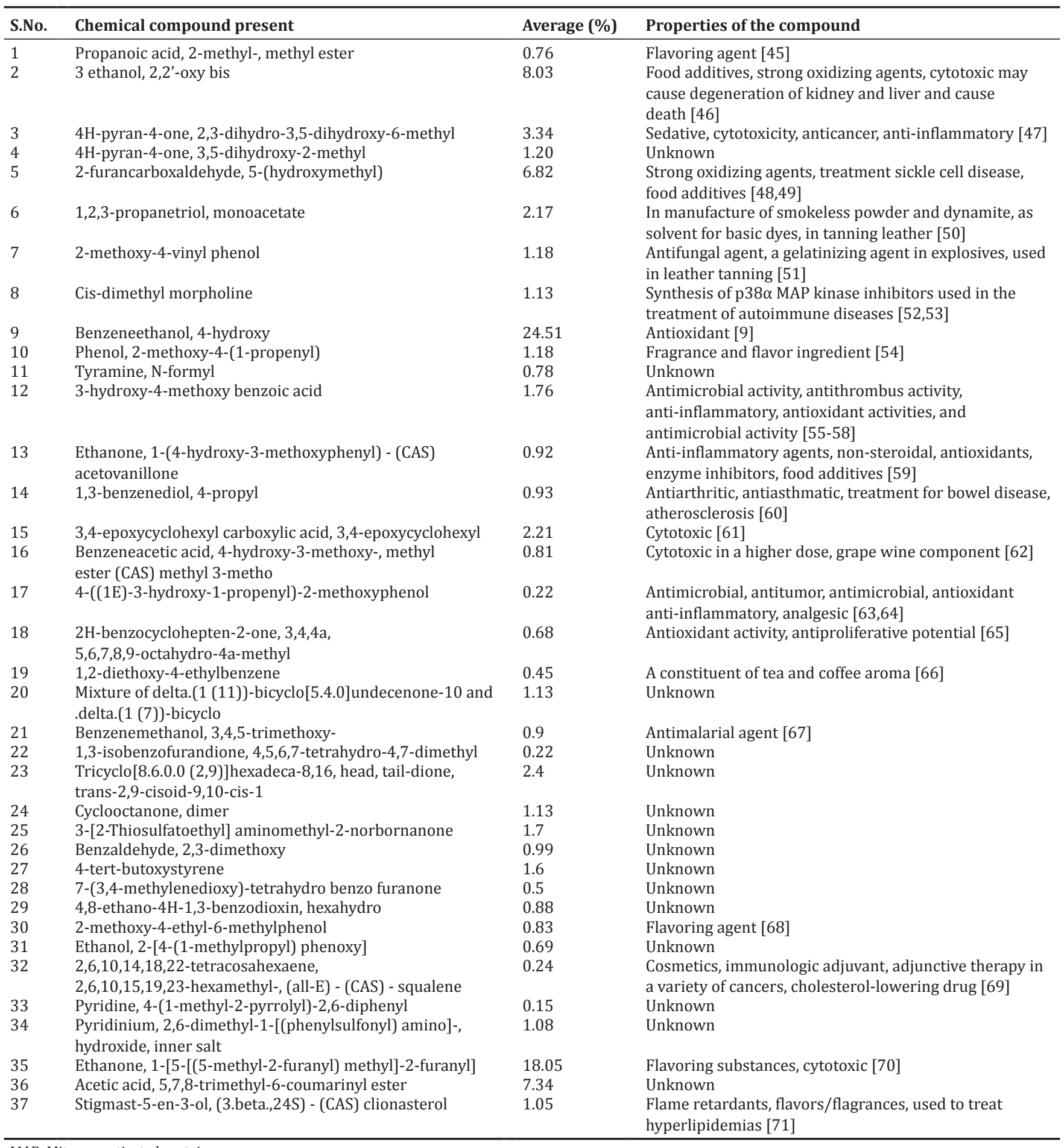

MAP: Mitogen-activated protein

observation confirms the positive activity of ethanolic extracts but the major pure compound benzene ethanol 4 hydroxy- was not the reason for the extract aphrodisiac activity.

$M L$

The results revealed that the animals treated with ethanolic leaf $(141.33 \pm 0.66)$ and bark $(203.66 \pm 2.02)$ extracts at the dose of $400 \mathrm{mg} / \mathrm{kg}$ body weight showed a significant decrease in ML, whereas the animals at $200 \mathrm{mg} / \mathrm{kg}$ body weight treated with ethanolic leaf $(287.66 \pm 1.44)$ and bark extracts $(276.33 \pm 0.87)$ showed a negligible decrease in ML.
However, the pure compound benzene ethanol 4 hydroxy- $(304 \pm 3.05)$ at $4.5 \mathrm{mg} / \mathrm{kg}$ body weight showed nil activity, even though it is a major compound in the leaf and bark ethanolic extracts, which is not responsible for its aphrodisiac activity.

IF

Appreciable IF was observed in ethanolic leaf extract $(0.68 \pm 0 ; 1.59 \pm 0.03)$ and ethanolic bark extract $(0.66 \pm 0.01 ; 1.25 \pm 0.01)$ at the dose of 200 and $400 \mathrm{mg} / \mathrm{kg}$ body weight. Whereas, the pure compound benzene ethanol 4 hydroxy- $(0.4 \pm 0)$ at $4.5 \mathrm{mg} / \mathrm{kg}$ body weight showed nil activity. 




Fig. 4: Gas chromatography and mass spectroscopy of crude Olea dioica Roxb. ethanolic leaf extract showing percentage of different compounds

Table 4: Effect of 0 . dioica Roxb. leaf and bark ethanolic extract and its pure compound on sexual behavior of male rats

\begin{tabular}{|c|c|c|c|c|c|c|c|}
\hline \multirow{2}{*}{$\begin{array}{l}\text { Group (dose } \mathrm{mg} / \mathrm{kg} \\
\text { body weight) }\end{array}$} & \multicolumn{7}{|c|}{ Different aphrodisiac activity (mean \pm SEM) } \\
\hline & $\begin{array}{l}\text { Number of } \\
\text { animals }\end{array}$ & MF & ML (seconds) & IF & IL (seconds) & AS & GG \\
\hline Control & 6 & $2.33 \pm 0.32$ & $310 \pm 0.57$ & $0.4 \pm 0$ & $796 \pm 2.51$ & $3.66 \pm 0.32$ & $2.33 \pm 0.32$ \\
\hline Sildenafil citrate (4.5) & 6 & $12 \pm 0.57^{* * *}$ & $100.33 \pm 0.87^{* * *}$ & $1.74 \pm 0 * * *$ & $197 \pm 1.52^{* * *}$ & $12 \pm 0.57^{* * *}$ & $6.33 \pm 0.33^{* * *}$ \\
\hline Ethanol leaf (200) & 6 & $5 \pm 0 * * *$ & $287.66 \pm 1.44$ & $0.68 \pm 0 * * *$ & $495.66 \pm 1.76^{* * *}$ & $6 \pm 0.57^{*}$ & $3 \pm 0.57$ \\
\hline Ethanol leaf (400) & 6 & $9.66 \pm 0.32^{* * *}$ & $141.33 \pm 0.66^{* * *}$ & $1.59 \pm 0.03^{* * *}$ & $218.66 \pm 1.44^{* * *}$ & $9.33 \pm 0.32 * * *$ & $5 \pm 0.57^{* *}$ \\
\hline Ethanol bark (200) & 6 & $4.66 \pm 0.32^{* *}$ & $276.33 \pm 0.87 *$ & $0.66 \pm 0.01^{* * *}$ & $691.33 \pm 6.66^{* * *}$ & $5.33 \pm 0.32 *$ & $2.33 \pm 0.33$ \\
\hline Ethanol bark (400) & 6 & $7.33 \pm 0.32^{* * *}$ & $203.66 \pm 2.02^{* * *}$ & $1.25 \pm 0.01^{* * *}$ & $425 \pm 3.05^{* * *}$ & $8.33 \pm 0.32^{* * *}$ & $3.66 \pm 0.66$ \\
\hline $\begin{array}{l}\text { Benzene ethanol } 4 \\
\text { hydroxy - (4.5) }\end{array}$ & 6 & $4 \pm 0^{*}$ & $304 \pm 3.05$ & $0.4 \pm 0$ & $767.66 \pm 5.66$ & $4 \pm 0.57$ & $2.66 \pm 0.32$ \\
\hline \multirow[t]{2}{*}{ One-way ANOVA } & $\mathrm{p}$ value & $<0.0001$ & $<0.0001$ & $<0.0001$ & $<0.0001$ & $<0.0001$ & $<0.0001$ \\
\hline & F value & 105.2 & 2742 & 1148 & 4341 & 45.31 & 9.389 \\
\hline
\end{tabular}

Each value is the mean \pm SEM of five rats, ${ }^{*} \mathrm{p}<0.05,{ }^{* *} \mathrm{p}<0.01,{ }^{* * *} \mathrm{p}<0.0001$ versus control. One-way ANOVA followed by Dunnet's t-test $\%$. 0. dioica: Olea dioica,

SEM: Standard error of the mean, MF: Mount frequency, ML: Mount latency, IF: Intromission frequency, IL: Intermission latency, AS: Anogenital sniffing, GG: Genital grooming

$I L$

The results revealed that the ethanolic leaf extract $(197 \pm 1.52$; $495.66 \pm 1.76)$ and ethanolic bark extract $(218.66 \pm 1.44 ; 691.33 \pm 6.66)$ at the concentration of 200 and $400 \mathrm{mg} / \mathrm{kg}$ body weight showed appreciable IL as compared to control animals. On the other hand, the pure compound benzene ethanol 4 hydroxy- at $4.5 \mathrm{mg} / \mathrm{kg}$ body weight showed negligible (767.66 \pm 5.66$)$ IL in comparison to rest of the group.

\section{$A S$}

A significant increase in number of AS was observed in the animals treated with ethanolic leaf extract $(9.33 \pm 0.32)$ and ethanolic bark extract $(8.33 \pm 0.32)$ at the dose of $400 \mathrm{mg} / \mathrm{kg}$ body weight and moderate activity was observed in the animals treated with ethanolic leaf extract $(6 \pm 0.57)$ and ethanolic bark extract $(5.33 \pm 0.32)$ at the dose of $200 \mathrm{mg} / \mathrm{kg}$ body weight. Whereas pure compound benzene ethanol 4 hydroxy- $(4 \pm 0.57)$ at $4.5 \mathrm{mg} / \mathrm{kg}$ body weight showed negligible AS compared to the control group.

\section{$G G$}

The results revealed that appreciable increase in a number of GG was observed in the animals treated with ethanolic leaf extract $(5 \pm 0.57)$
$400 \mathrm{mg} / \mathrm{kg}$ body weight and the standard Sildenafil citrate $4.5 \mathrm{mg} / \mathrm{kg}$ body weight, whereas other groups showed negligible GG.

\section{DISCUSSION}

O. dioica Roxb. plant is unexplored for many pharmacological activities but aphrodisiac activity is accidental one because, even though it was used by the tribes for various treatments such as cancer, snake bite, skin disease treatment, rheumatism, fever [8,9], and experimentally proved for antibacterial, antifungal activity, antioxidant, and cytotoxic properties [10-12], but aphrodisiac activity of this plant was not been reported in tribal history and by the scientific experiments. We excluded the petroleum ether and chloroform extracts of 0 . dioica Roxb. leaf and bark due the negligible metabolites present in it and it is confirmed by qualitative preliminary phytochemical analysis (Table 1).

GC-MS analysis of 0 . dioica Roxb. leaf ethanolic extract revealed the presence of 38 compounds, they were benzene-ethanol, 4-hydroxy(37.44), 2-amino-3-(3,4-dihydroxy-phenyl)-propionic acid (16.47), 1,3-benzenediol, 4-propyl- (6.46), 2,4-dimethoxytoluene - (5.01), benzaldehyde, 2,3-dimethoxy - (4.63), 2-furancarboxaldehyde, 5-(hydroxymethyl)- (3.81), benzene, 1-(bromomethyl)-3-nitro- 


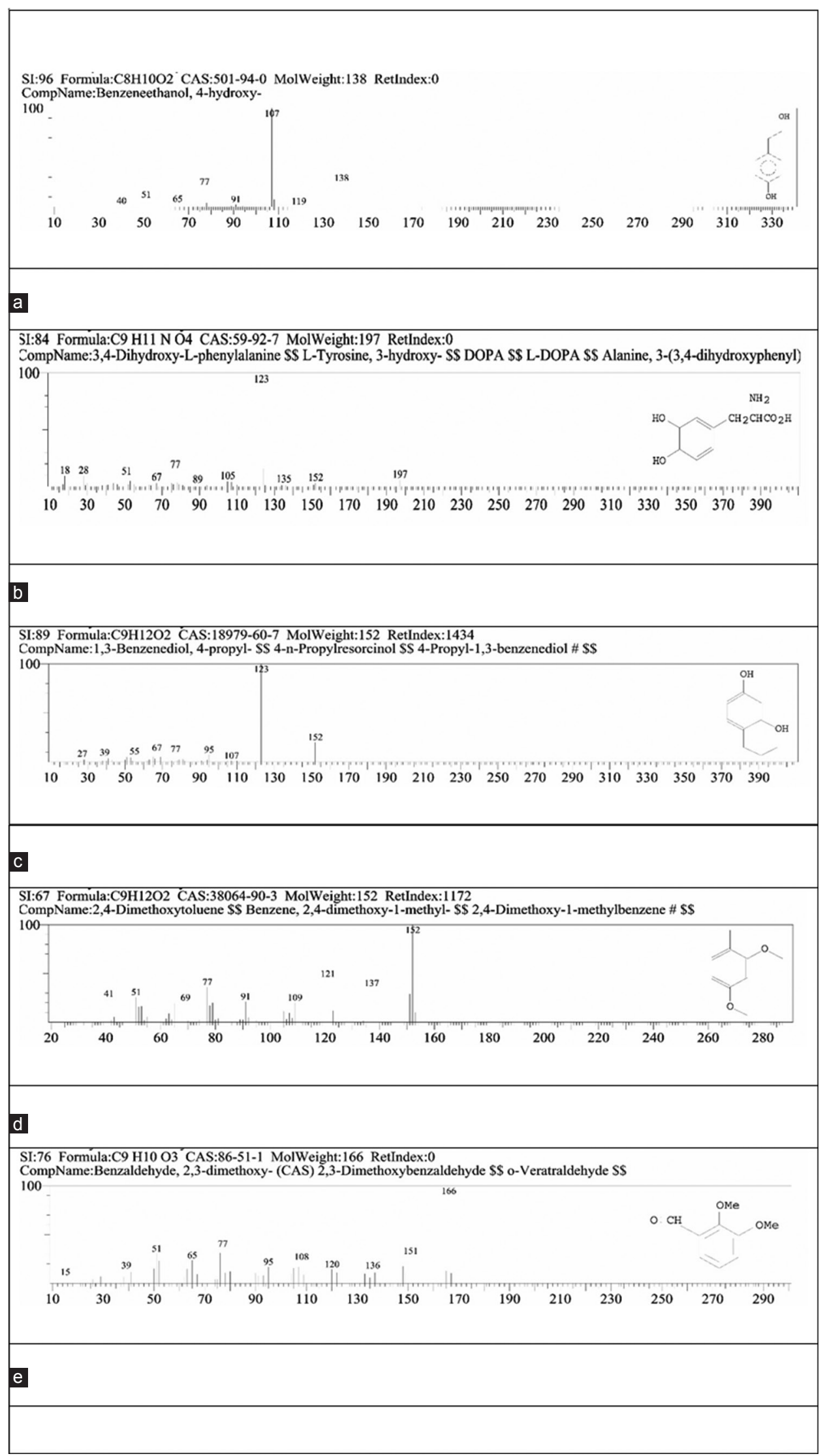

Fig. 5: Mass spectrum of a major percentage of the constituent present in crude leaf ethanolic extract of Olea dioica Roxb. 


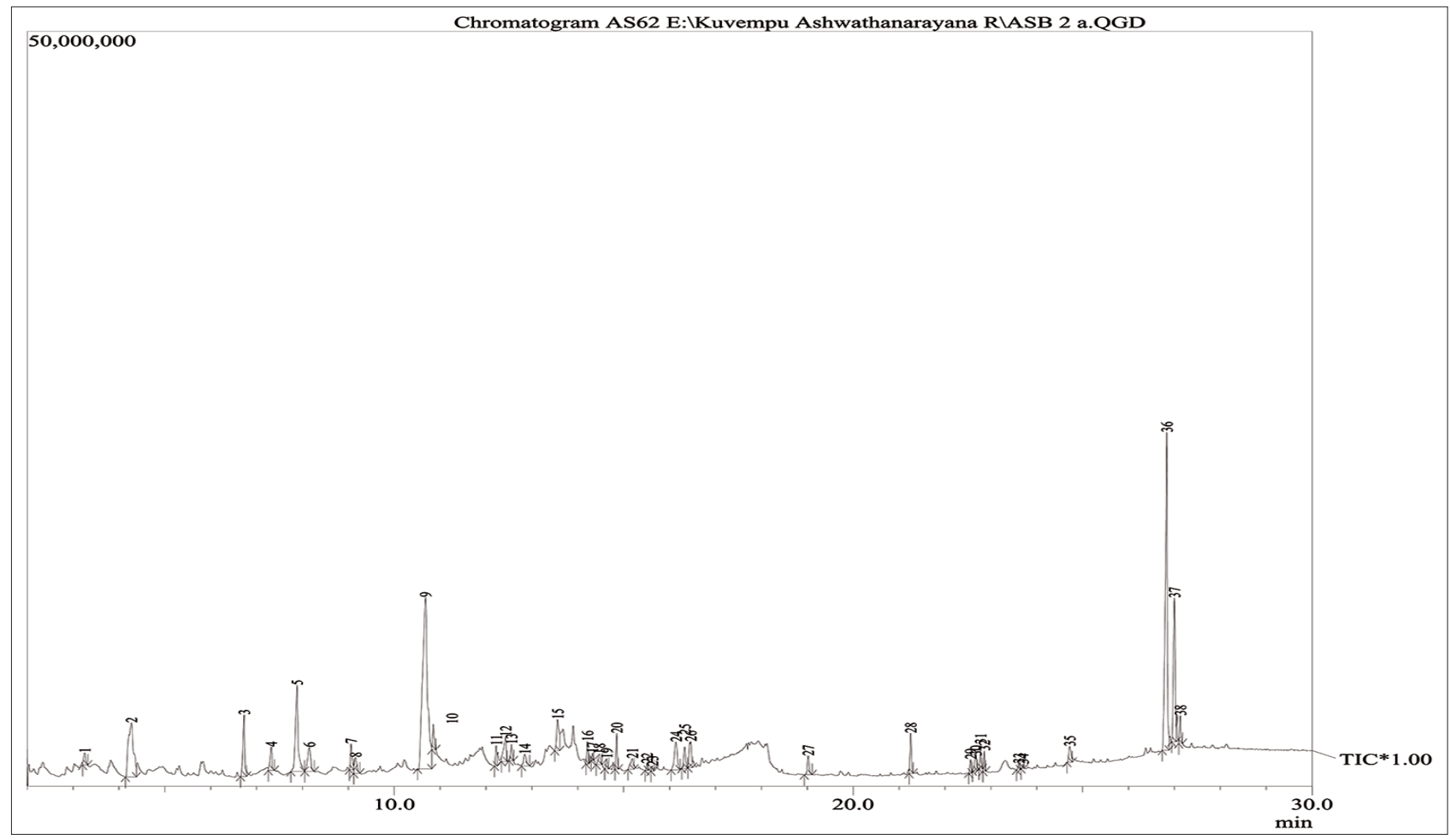

Fig. 6: Gas chromatography and mass spectroscopy chromatogram of Olea dioica bark ethanolic extract

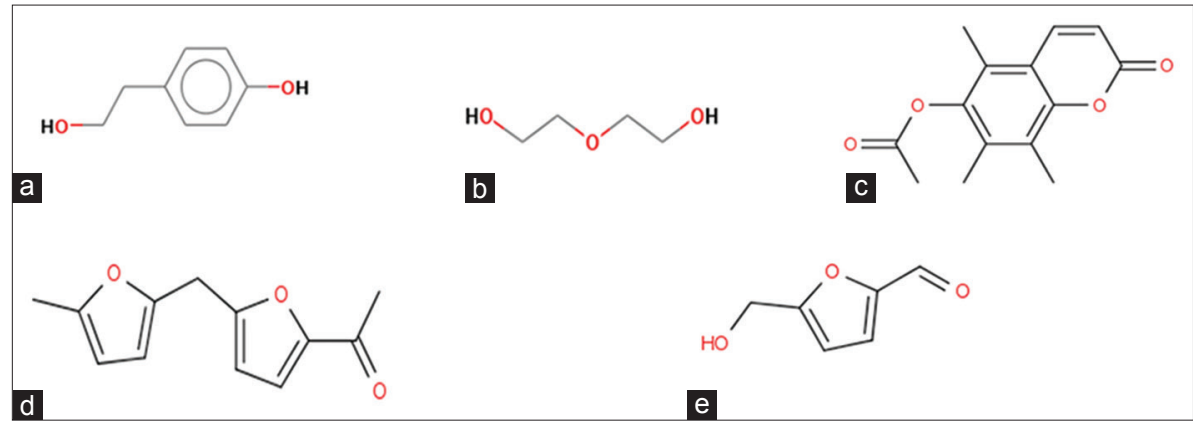

Fig. 7: Major percentage of constituent present in the gas chromatography and mass spectroscopy analysis of crude bark ethanolic extract of Olea dioica Roxb. (a) Benzenethanol 4 hydroxy-, (b) 3 ethanol, 2,2'-oxybis-, (c) Acetic acid, 5,7,8-trimethyl-6-coumarinyl ester, (d) ethanone, 1-[5-[(5-methyl-2-furanyl) methyl]-2-furanyl]-, (e) 2-furancarboxaldehyde, 5-(hydroxymethyl)-

(2.82), 4H-pyran-4-one, 2,3-dihydro-3,5-dihydroxy-6-methyl- (2.22), glyceraldehyde (1.97), cyclopentane, 1-acetyl-1,2-epoxy- (1.62), 4-tertbutoxystyrene (1.51), tyramine, N-formyl- (1.28), 1,2,3-propanetriol, diacetate (1.25), pyridinium, 2,6-dimethyl-1-[(phenylsulfonyl)amino]-, hydroxide (1.14), 2H-pyran-5-carboxylic acid, 2-oxo-, methyl ester (1.08), borolo[1,2-a]borine, octahydro- (1.01), 2H-pyran, tetrahydro4-methyl-2-(2-methyl-1-propenyl)- $\quad(0.85), \quad 2,4$-hexadienedioic acid, 3,4-diethyl-, dimethyl ester, (E, Z)- (0.84), 2,3-dihydrobenzofuran (0.82), benzoic acid, 3-amino-6-(4-morpholyl)- (0.79), formamide, $\mathrm{N}$-(cyanomethyl)- (0.71), cyclohexene, 1,5,5-trimethyl-6acetylmethyl- (0.6), benzenamine, 3,4-dimethyl- (0.59), 2-methoxy-4vinylphenol (0.52), 4H-pyran-4-one, 3,5-dihydroxy-2-methyl- (0.52), 3,7,11,15-tetramethyl-2-hexadecen-1-ol (0.49), benzeneacetic acid, 4-hydroxy-3-methoxy-, methyl ester (0.41), 2-acetyl-2-hydroxygamma-butyrolactone (0.41), 2-(2-hydroxy-2-phenylethyl)-3,5,6trimethylpyrazine (0.38), pentanoic acid, 4-oxo- $(0.37)$, phenylethyl alcohol (0.33), 2H-benzocyclohepten-2-one, 3,4,4a,5,6,7,8,9-octahydro(0.32), 2,4-hexanedione (0.29), cyclohexanone, 2,6-dimethyl-
(0.26), benzenemethanol (0.23), 3-hydroxy-2(5H)-furanone (0.23), 1,2-benzenediol (0.17), and 2-furancarboxylic acid (0.16). In that 15 compounds were unknown, no scientific literature was found about its pharmacological properties, and the rest of the 23 compounds has known pharmacological properties (Table 2).

GC-MS analysis of 0 . dioica Roxb. bark ethanolic extract revealed the presence of 37 compounds, they were benzene-ethanol, 4-hydroxy- (24.51), ethanone, 1-[5-[(5-methyl-2-furanyl)methyl]2-furanyl]- (18.05), 3 ethanol, 2,2'-oxy bis- (8.03), acetic acid, 5,7,8-trimethyl-6-coumarinyl ester (7.34), 2-furancarboxaldehyde, 5-(hydroxymethyl)- (6.82), 4H-pyran-4-one, 2,3-dihydro-3,5dihydroxy-6-methyl- (3.34), tricyclo[8.6.0.0(2,9)] hexadeca8,16,head,tail-dione, trans-2,9- (2.4), 3,4-epoxycyclohexyl carboxylic acid, 3,4-epoxycyclohexyl (2.21), 1,2,3-propanetriol, monoacetate (2.17), 3-hydroxy-4-methoxy benzoic acid (1.76), 3-[2-thiosulfatoethyl] aminomethyl-2-norbornanone (1.7), 4-tert-butoxystyrene (1.6), 4H-pyran-4-one, 3,5-dihydroxy-2-methyl- (1.2), 2-methoxy-4- 


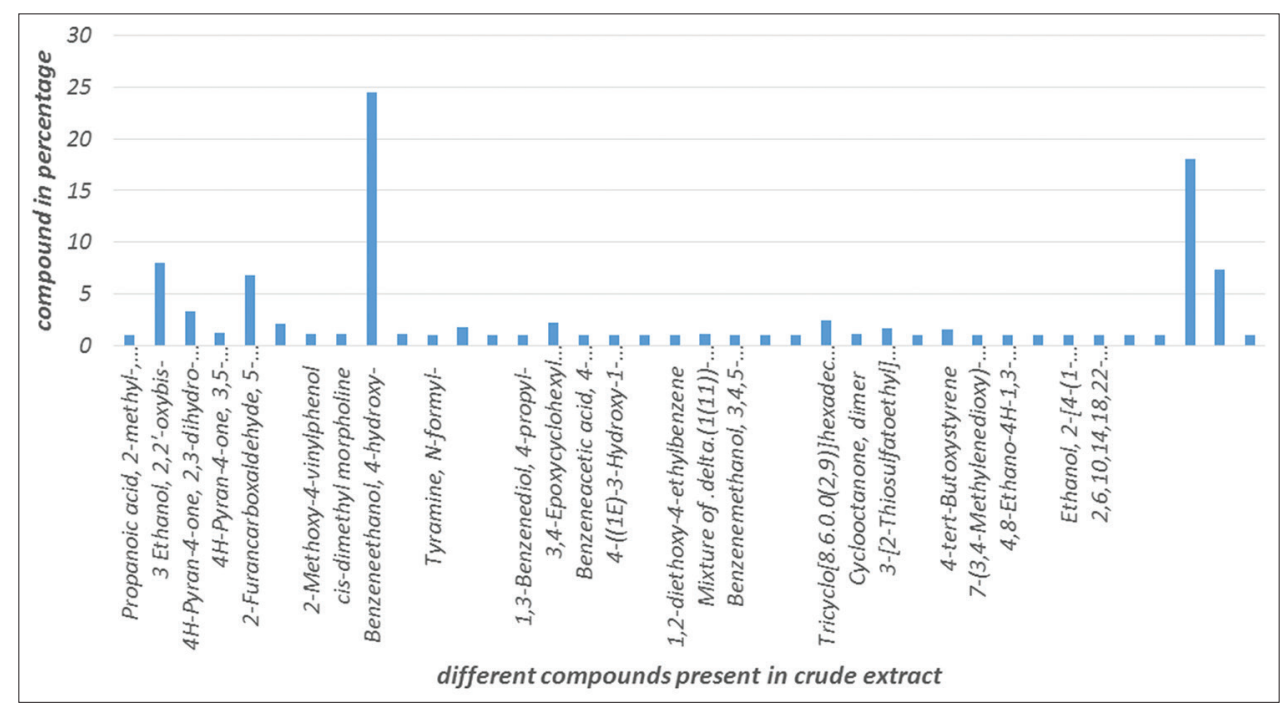

Fig. 8: Gas chromatography and mass spectroscopy of crude Olea dioica Roxb. ethanolic bark extract showing percentage of different compounds

vinyl phenol (1.18), phenol, 2-methoxy-4-(1-propenyl)- (1.18), cisdimethyl morpholine (1.13), mixture of delta(1(11))-bicyclo[5.4.0] undecenone-10 and .delta.(1(7))-bicyclo (1.13), cyclooctanone, dimer (1.13), hydroxide, inner salt (1.08), stigmast-5-en-3ol, (3.beta.,24S)- (1.05), benzaldehyde, 2,3-dimethoxy- (0.99), 1,3-benzenediol, 4-propyl- (0.93), ethanone, 1-(4-hydroxy-3methoxyphenyl)- (0.92), benzenemethanol, 3,4,5-trimethoxy- (0.9), 4,8-ethano-4H-1,3-benzodioxin, hexahydro- (0.88), 2-methoxy4-ethyl-6-methylphenol (0.83), benzeneacetic acid, 4-hydroxy-3methoxy-, methyl ester (0.81), tyramine, $\mathrm{N}$-formyl- $(0.78)$, propanoic acid, 2-methyl-, methyl ester (0.76), ethanol, 2-[4-(1-methylpropyl) phenoxy]- (0.69), 2H-benzocyclohepten-2-one, 3,4,4a,5,6,7,8,9octahydro-4a-methyl-(0.68), 7-(3,4-methylenedioxy)-tetrahydro benzo furanone (0.5), 1,2-diethoxy-4-ethylbenzene (0.45), 2,6,10,14,18,22-tetracosahexaene, 2,6,10,15,19,23-hexamethyl-, (all-E)- (0.24), 4-((1E)-3-hydroxy-1-propenyl)-2-methoxyphenol (0.22), 1,3-isobenzofurandione, 4,5,6,7-tetrahydro-4,7-dimethyl(0.22) and pyridine, 4-(1-methyl-2-pyrrolyl)-2,6-diphenyl- (0.15). In that 15 compounds were unknown, no scientific literature was found about its pharmacological properties, and the rest of the 22 compounds has known pharmacological properties (Table 3).

By the results, it is revealed that the 0 . dioica Roxb. leaf and bark ethanolic extracts and its pure compound showed excellent aphrodisiac activity in all tested parameters.

In MF test, ethanolic leaf at 200 and $400 \mathrm{mg} / \mathrm{kg}$ body weight and ethanolic bark extract at $400 \mathrm{mg} / \mathrm{kg}$ body weight showed significant activity, ethanolic bark extract at $200 \mathrm{mg} / \mathrm{kg}$ body weight showed moderate activity and the pure compound benzene ethanol 4-hydroxyat $4.5 \mathrm{mg} / \mathrm{kg}$ body weight showed negligible MF (Table 4 ).

In $\mathrm{ML}$ test, ethanolic leaf at $400 \mathrm{mg} / \mathrm{kg}$ body weight and ethanolic bark extract at $400 \mathrm{mg} / \mathrm{kg}$ body weight showed significant activity, ethanolic leaf extract at $200 \mathrm{mg} / \mathrm{kg}$ body weight showed moderate activity and the ethanolic bark and pure compound benzene ethanol 4-hydroxy- at $4.5 \mathrm{mg} / \mathrm{kg}$ body weight showed negligible $\mathrm{ML}$ (Table 4).

In IF and IL tests, all the extracts showed excellent activity except pure compound. In AS, ethanolic leaf and bark extract at $400 \mathrm{mg} / \mathrm{kg}$ body weight showed excellent activity and in $200 \mathrm{mg} / \mathrm{kg}$ body weight showed moderate activity and pure compound showed nil grooming. In GG, all the tested compound showed nil grooming except the standard sildenafil citrate (4.5) and ethanolic leaf extract at $400 \mathrm{mg} / \mathrm{kg}$ body weight (Table 4).

The leaf ethanolic extract showed excellent activity comparably with the bark ethanolic extract. leaf ethanolic extract has 2 -amino3-(3,4-dihydroxy-phenyl)-propionic acid in $16.47 \%$. which had $99 \%$ similar structure to L-dopa ((2S)-2-amino-3-(3,4-dihydroxyphenyl) propanoic acid) a psychoactive drug mainly used in the treatment of Parkinson's disease and many research articles [72-76] already proven that L-dopa has strong aphrodisiac properties, so similar structured compound may also the main reason for the aphrodisiac properties of leaf ethanolic extract and in bark ethanolic extract unknown compound/compounds may influence the aphrodisiac activity in tested rats.

This is the first paper to report to prove aphrodisiac activity of $O$. dioica Roxb. which is unexplored till now by traditional practitioners as well as scientific communities. Further studies such as sperm count, sperm motility, sperm morphology [77] and estrous cycle, hematological parameters, and serum biochemical parameters [78] should be done to observe the actual pathway of the crude extract which is enhancing aphrodisiac activity.

\section{CONCLUSION}

By the above observation, it is concluded that the pure compound benzene ethanol 4-hydroxy- even though a major constituent of leaf and bark ethanolic extracts is not responsible for the aphrodisiac effect and leaf ethanolic extract have 2-amino-3-(3,4-dihydroxy-phenyl)propionic acid which has similar structure to the L-dopa [72-76] a psychoactive drug mainly used in the treatment of Parkinson's disease and sexual disorders, may be the reason for aphrodisiac activity in leaf ethanolic extract and in bark ethanolic extract unknown compound/ compounds may influence the aphrodisiac activity in tested rats that should be studied further.

\section{ACKNOWLEDGMENT}

The authors are thankful to the Department of Applied Botany, Kuvempu University, for providing facilities. 




Fig. 9: Mass spectrum of a major percentage of the constituent present in crude bark ethanolic extract of Olea dioica Roxb. 


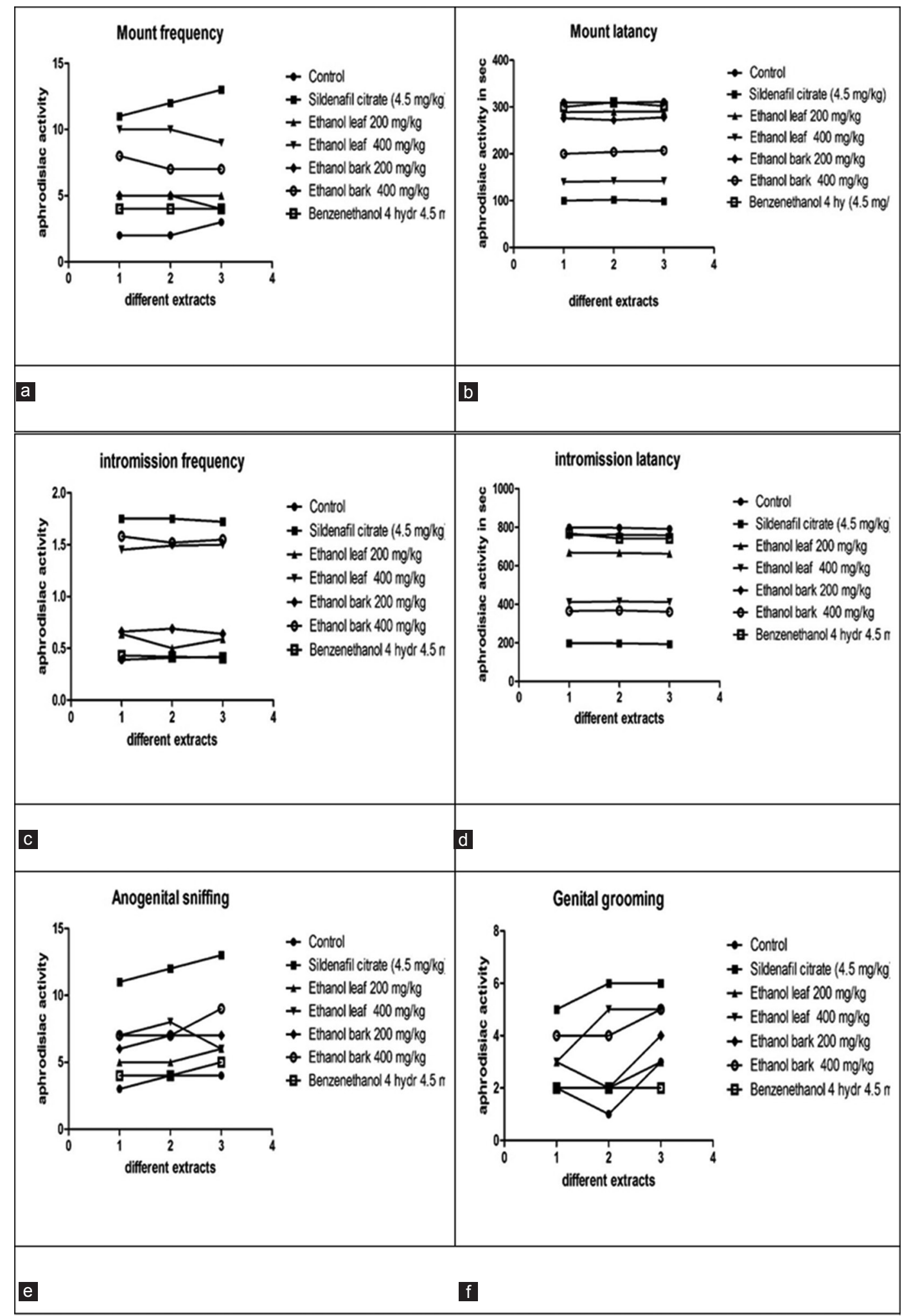

Fig. 10: (a-f) Aphrodisiac activity of Olea dioica Roxb. leaf and bark ethanolic extract using different parameters in different concentration with pure compound and standard

\section{REFERENCES}

1. Elferink JG. Aphrodisiac use in pre-columbian Aztec and Inca cultures. $\mathrm{J}$ Hist Sex 2000;9(1-2):25-36.

2. Melnyk JP, Marcone MF. Aphrodisiacs from plant and animal sources A review of current scientific literature. Food Res Int 2011;44:840-50.
3. Blackwell B. Antidepressant drugs. In: Dukes MN Meyer's Side Effects of Drugs. Amsterdam: Elsevier; 1984. p. 24-61.

4. Kumar S, Kumar JV, Selvaraj R. Aphrodisiac activity of Cycas circinalis $\mathrm{L}$ and Ionidium suffruticosum Ging on male wister albino rats. Asian $\mathrm{J}$ Pharm Clin Res 2013;6(3):215-7.

5. Shekar S, Vazir M, Kempanna B, Miryala SK, Subedi A. Effect of 
yohimbine on clomipramine-induced sexual dysfunction in male rats. Asian J Pharm Clin Res 2017;10(2):92-6.

6. Pascal JP. Wet Evergreen Forests of the Western Ghats of India. Vol. 11. France: Institut Francais De Pondicherry; 1988. p. 309.

7. Kholkute SD. Coordinating Unit of Survey of Medicinal Plants of Western Ghats of India. A Project Report Submitted. New Delhi: Indian Council of Medical Research; 2008. p. 16-7.

8. Pullaiah T. Biodiversity in India. Vol. 4. New Delhi: Regency Publications; 2006. p. 281-2.

9. Yesodharan K, Sujana KA. Ethnomedicinal knowledge among Malamalasar tribe of Parambikulam wildlife sanctuary, Kerala. Indian J Tradit Knowl 2007;6(3):481-5.

10. Ashwathanarayana R, Naika R. Comparative study of different solvent extract of Olea dioica Roxb. Western Ghats, Karnataka, against selected plant and animal pathogenic bacteria. J Pharm Bio Res 2015;3(1):217-22.

11. Ashwathanarayana R, Naika R. Preliminary phytochemical and antimicrobial properties of Olea dioica Roxb. Bark extract collected from the Western Ghats, Karnataka, India. J Pharmacogn Phytochem 2015;4(4):156-60.

12. Ashwathanarayana R, Naika R. Study on antioxidant and cytotoxic properties of Olea dioica Roxb. crude extract and its pure compound collected from Western Ghats, Karnataka, India. Asian J Pharm Clin Res 2017;10(2):356-67.

13. Rao GS, Padmalatha HV, Udupa ES. Diversity of tree species in Sharavathi wildlife sanctuary, Shivamogga. Int J Curr Res 2016;8(8):36809-12.

14. De-Castro MD, Ayuso LE. Soxhlet extraction of solid materials: An outdated technique with a promising innovative future. Anal Chim Acta 1998;369:1-10.

15. Harborne JB. Phytochemical Methods: A Guide to Modern Techniques of Plant Analysis. $3^{\text {rd }}$ ed. New York: Chapman and Hall Co.; 1998. p. 1-302.

16. Gartlan JS, McKey DB, Waterman PG, Mbi CN, Strusaker TT. A comparative study of the phytochemistry of two African rain forests. Biochem Syst Ecol 1980;8:401-22.

17. Singh G, Mukherjee T. Herbal aphrodisiacs. Indian Drugs 1998;35(4):175-82.

18. Tripathi KD. Essentials of Medical Pharmacology. $4^{\text {th }}$ ed. New Delhi: Jaypee Brothers; 1999. p. 298-325.

19. Subramoniam A, Madhavachandran V, Rajasekharan S, Pushpangadan P. Aphrodisiac property of Trichopus zeylanicus extract in male mice. J Ethnopharmacol 1997;57(1):21-7.

20. Kothari CR. Research Methodology. $2^{\text {nd }}$ ed. New Delhi: New Age International Publishers; 2004. p. 256-61.

21. Wani JA, Achur RN, Nema KR. Phytochemical screening and aphrodisiac activity of Asparagus racemosus. Int J Pharm Sci Drug Res 2011;3(2):112-5

22. Adeneye AA, Ajagbonna OP, Adeleke TI, Bello SO. Preliminary toxicity and phytochemical studies of the stem bark aqueous extract of Musanga cecropioides in rats. J Ethnopharmacol 2006;105(3):374-9.

23. Panten U, Ishida H, Beckmann J. Effects of D-glyceraldehyde and 3-o-methylglucose upon fluorescence of reduced pyridine nucleotides from perifused isolated pancreatic islets. Horm Res 1976;7(3):164-71.

24. Pubchem-2(5H)-Furanone $\left(\mathrm{C}_{4} \mathrm{H}_{4} \mathrm{O}_{2}\right)$. Available from: https://www. pubchem.ncbi.nlm.nih.gov/compound/2_5H_-Furanone.

25. Lucchini JJ, Corre J, Cremieux A. Antibacterial activity of phenolic compounds and aromatic alcohols. Res Microbiol 1990;141(4):499-510.

26. Zilz TR, Griffiths HR, Coleman MD. Apoptotic and necrotic effects of hexanedione derivatives on the human neuroblastoma line SK-N-SH. Toxicology 2007;231(2-3):210-4

27. Jadhav V, Kalase V, Patil P. GC-MS analysis of bioactive compounds in methanolic extract of Holigarna grahamii (wight) Kurz. Int J Herb Med 2014;2(4):35-9.

28. PubChem-2-Furancarboxylic Acid. Available from: https://www. pubchem.ncbi.nlm.nih.gov/compound/2-furoic acid.

29. Senthamarai SV, Basker A. Phytochemical analysis and GC-MS profiling in the leaves of Sauropus androgynus (1) MERR. Int J Drug Dev Res 2012;4(1):162-7.

30. Corre J, Lucchini JJ, Mercier GM, Cremieux A. Antibacterial activity of phenethyl alcohol and resulting membrane alterations. Res Microbiol 1990;141(4):483-97.

31. Moorthy V, Boominathan M. Comparative antimicrobial activities of Morus alba crude extract and fraction against Staphylococcus aureus. Int J Inst Pharm Life Sci 2011;1(2):48-56.

32. Kumar PP, Kumaravel S, Lalitha C. Screening of antioxidant activity, total phenolics and GC-MS study of Vitex negundo. Afr J Biochem Res
2010;4(7):191-5

33. PubChem -4H-pyran-4-one,3,5-dihydroxy-2-methyl. Available from: https://www.pubchem.ncbi.nlm.nih.gov/compound/5-Hydroxymaltol.

34. The Government of Canada, Environment, and Climate Change Canada, 1,2-benzenediol (catechol), screening assessment for 1,2-benzenediol (120-80-9), July; 2008. Available from: https://www.ec.gc.ca/eseees/04FDC10E-0C72-41B2-8040-91B7BB43AE38/batch1 120-80-9 en.pdf.

35. de Castro Oliveira LG, Brito LM, de Moraes Alves MM, Amorim LV, Sobrinho-Júnior EP, de Carvalho CE, et al. In vitro effects of the neolignan 2,3-dihydrobenzofuran against leishmania amazonensis. Basic Clin Pharmacol Toxicol 2017;120(1):52-8.

36. Diaz P, Phatak SS, Xu J, Fronczek FR, Astruc-Diaz F, Thompson CM, et al. 2,3-dihydro-1-benzofuran derivatives as a series of potent selective cannabinoid receptor 2 agonists: Design, synthesis, and binding mode prediction through ligand-steered modeling. ChemMedChem 2009;4(10):1615-29

37. Encyclopedia - The Free Dictionary. Available from: http://www. encyclopedia2.thefreedictionary.com/1,2,3-propanetriol

38. PubChem - 2-Methoxy-4-vinylphenolC $\mathrm{H}_{0} \mathrm{H}_{10}$ Available from: https://www.pubchem.ncbi.nlm.nih.gov/compound/2-Methoxy-4vinylphenol.

39. Subashini S, Rameshkannan V, Mani P. Phytochemical and GC-MS analysis of bioactive compounds from Borassus flabellifer Linn root. Eur J Mol Biol Biochem 2015;2(3):148-52

40. Garzon-Aburbeh A, Jacques HP, Claesen M, Dumont P. A lymphotropic prodrug of L-Dopa: Synthesis, pharmacological properties, and pharmacokinetic behavior of 1,3-dihexadecanoyl-2-[(S)-2-amino-3(3,4-dihydroxy phenyl) propanoyl]propane-1,2,3-triol. J Med Chem 1986;29(5):687-91.

41. Dey P, Dutta S, Chaudhuri TK. Comparative phytochemical profiling of Clerodendrum infortunatum L. Using GC-MS method coupled with multivariate statistical approaches. Metabolomics 2015;5:3.

42. PubChem - Phytol $\mid \mathrm{C}_{20} \mathrm{H}_{40} \mathrm{O}$. Available from: https://www.pubchem. ncbi.nlm.nih.gov/compound/5366244.

43. PubChem - Roseoxide/2H-Pyran,tetrahydro-4-methyl-2-(2-methyl-1propenyl)- $\mid \mathrm{C}_{10} \mathrm{H}_{18} \mathrm{O}$. Available from: https://www.pubchem.ncbi.nlm. nih.gov/compound/Rose_oxide.

44. PubChem - 3,4-Dimethylaniline $\mid \mathrm{C}_{8} \mathrm{H}_{11} \mathrm{~N}$. Available from: https://www. pubchem.ncbi.nlm.nih.gov/compound/3_4-Dimethylaniline.

45. PubChem - Methyl Isobutyrate- $\mathrm{C}_{5} \mathrm{H}_{10} \mathrm{O} 2$. Available from: https://www. pubchem.ncbi.nlm.nih.gov/compound/methyl isobutyrate.

46. PubChem - 3 Ethanol, 2,2'-Oxybis $\mathrm{C}_{4} \mathrm{H}_{10} \mathrm{O}_{3}$ Available from: https:// www.pubchem.ncbi.nlm.nih.gov/compound $/ 53249256$.

47. Yu X, Zhao M, Liu F, Zeng S, Hu J. Identification of 2,3-dihydro-3,5dihydroxy-6-methyl-4H-pyran-4-one as a strong antioxidant in glucosehistidine Maillard reaction products. Food Res Int 2013;51(1):397-403.

48. PubChem - 5-hydroxymethylfurfural|C6H6O3. Available from: https:// www.pubchem.ncbi.nlm.nih.gov/compound/5-hydroxymethylfurfural.

49. Wikipedia - Hydroxymethylfurfural. Available from: https://www. en.wikipedia.org/wiki/hydroxymethylfurfural.

50. PubChem - 1,2,3-propanetriol, monoacetate. https://www.pubchem. ncbi.nlm.nih.gov/compound/Acetin.

51. Fukai S, Tanimoto S, Maeda A, Fukuda H, Okada Y, Nomura M. Pharmacological activity of compounds extracted from persimmon peel (Diospyros kaki THUNB.). J Oleo Sci 2009;58(4):213-9.

52. PubChem - Cis-2,6-dimethylmorpholine. Available from: https://www. pubchem.ncbi.nlm.nih.gov/compound/cis-2 6-dimethylmorpholine.

53. Regan J, Capolino A, Cirillo PF, Gilmore $\bar{T}$, Graham AG, Hickey E, et al. Structure-activity relationships of the p38alpha MAP kinase inhibitor 1-(5-tert-butyl-2-p-tolyl-2H-pyrazol-3-yl)-3-[4-(2-morpholin4-yl-ethoxy)naph-thalen-1-yl]urea (BIRB 796). J Med Chem 2003;46(22):4676-86.

54. PubChem - Phenol,2-methoxy-4-(1-propenyl). Available from: https:// www.pubchem.ncbi.nlm.nih.gov/compound/Isoeugenol.

55. Fernández MA, Sáenz MT, García MD. Anti-inflammatory activity in rats and mice of phenolic acids isolated from Scrophularia frutescens. J Pharm Pharmacol 1998;50(10):1183-6.

56. Tung YT, Wu JH, Kuo YH, Chang ST. Antioxidant activities of natural phenolic compounds from Acacia confusa bark. Bioresour Technol 2007;98(5):1120-3.

57. Cueva C, Moreno-Arribas MV, Martín-Alvarez PJ, Bills G, Vicente MF, Basilio A, et al. Antimicrobial activity of phenolic acids against commensal, probiotic and pathogenic bacteria. Res Microbiol 2010;161(5):372-82

58. Lee HC, Jenner AM, Low CS, Lee YK. Effect of tea phenolics and their aromatic fecal bacterial metabolites on intestinal microbiota. Res 
Microbiol 2006;157(9):876-84

59. PubChem - Ethanone,1-(4-hydroxy-3-methoxyphenyl). Available from: https://www.pubchem.ncbi.nlm.nih.gov/compound/Acetovanillone.

60. PubChem - 1,3-benzenediol,4-propyl. Available from: https://www. pubchem.ncbi.nlm.nih.gov/compound/4-Propylresorcinol.

61. PubChem - 3,4-epoxycyclohexyl,CarboxylicAcid,3,4-Epoxycyclohexy 1. Available from: https://www.pubchem.ncbi.nlm.nih.gov/compound /2386-87-0.

62. Flamini R, Traldi P. Mass Spectrometry in Grape and Wine Chemistry. UK: John Wiley and Sons; 2009. p. 232.

63. Gopalakrishnan S, Vadivel E. GC-MS analysis of some bioactive constituents of Mussaenda frondosa Linn. Int J Pharm Bio Sci 2011;2(1):316-9.

64. PubChem - 4-((1E)-3-Hydroxy-1-propenyl)-2-methoxyphenol. Available from: https://www.pubchem.ncbi.nlm.nih.gov/compound/ coniferyl_alcohol.

65. Chaudhary A, Choudhary S, Sharma U, Vig AP, Arora S. In vitro evaluation of Brassica sprouts for its antioxidant and antiproliferative potential. Indian J Pharm Sci 2016;78(5):615-23

66. PubChem - 1,2-dimethoxy-4-ethylbenzene. Available from: https://www.pubchem.ncbi.nlm.nih.gov/compound/4-Ethyl-1_2dimethoxybenzene.

67. PubChem - Benzenemethanol,3,4,5-trimethoxy. Available from: https://www.pubchem.ncbi.nlm.nih.gov/compound/3_4_5Trimethoxybenzyl alcohol.

68. PubChem - 2-Methoxy-4-Ethyl-6-Methylphenol. Available from: https://www.pubchem.ncbi.nlm.nih.gov/compound/4-Ethyl-2- methoxyphenol.

69. Kelly GS. Squalene and its potential clinical uses. Altern Med Rev 1999;4(1):29-36

70. PubChem - Ethanone,1-[5-[(5-methyl-2-furanyl)methyl]-2furanyl]. Available from: https://www.pubchem.ncbi.nlm.nih.gov/ compound $/ 579178$

71. PubChem - Stigmast-5-en-3-ol,(3.beta.,24S). Available from: https:// www.pubchem.ncbi.nlm.nih.gov/compound/Clionasterol.

72. Tagliamonte A, Fratta W, Gessa GL. Aphrodisiac effect of L-DOPA and apomorphine in male sexually sluggish rats. Experientia 1974;30(4):381-2

73. Angrist B, Gershon S. Clinical effects of amphetamine and L-DOPA on sexuality and aggression. Compr Psychiatry 1976;17(6):715-22.

74. Ananthakumar KV, Srinivasan KK, Shanbhag T, Rao SG. Aphrodisiac activity of the seeds of Mucuna pruriens. Indian Drugs 1994;31:321-7.

75. Guohua H, Yanhua L, Rengang M, Dongzhi W, Zhengzhi M, Hua Z. Aphrodisiac properties of Allium tuberosum seeds extract. J Ethnopharmacol 2009;122(3):579-82.

76. Narayanswamy VB, Setty MM, Malini S, Shirwaikar A. Preliminary aphrodisiac activity of Hybanthus enneaspermus in rats. Pharmacologyonline 2007;1:152-61

77. Daud D, Azahar A, Abidin SS, Tawang A. The effects of Cosmos caudatus and Piper sarmentosum aqueous extracts on male mice fertility. Int J Pharm Pharm Sci 2015;7(12):296-8.

78. Mensah KB, Benneh C, Boakye-Gyasi E. Ethanol root extract of the African aphrodisiac, Mondia whitie (periplocaceae), possess estrogenic activity. Int J Pharm Pharm Sci 2015;7(5):284-7. 